\title{
ISTORIJSKI RAZVOJ STRATEGIJSKOG MENADŽMENTA
}

\author{
Antonio Mak*, Nenad V. Kovačević \\ Univerzitet odbrane u Beogradu, Vojna akademija \\ Mitar Kovač
}

Univerzitet Edukons, Fakultet za projektni i inovacioni menadžment,

Beograd

U radu je analiziran istorijski razvoj menadžmenta i strategijskog menadžmenta kroz tri vremenska perioda: (1) do 1880. godine, (2) od 1880 do 1945. godine i (3) od 1945. godine do danas. Primena strategijskoj menadžmenta za potrebe sistema odbrane objašnjena je kroz funkcionisanje koncepta PPBI u sistemu odbrane Republike Srbije.

Ključne reči: menadžment, strategijski menadžment, sistem PPBI

Uvod

Dadi osvajanja novih prostora i zaštite sopstvenih postojećih staništa ljudi su oduvek bavili poboljšanjem efikasnosti i efektivnosti realizacije različitih poslova, poduhvata i zadataka. Istorijski posmatrano, ljudi su najpre sporadično na osnovu intuicije i iskustva, a vremenom unoseći nova i prethodno stečena znanja formirali postupke koji su vodili stvaranju jedne posebne veštine, a potom i nauke koja je bila sve potrebnija i neophodnija. Nauka koja objedinjuje sve navedeno formira se početkom 20. veka i dobija naziva menadžment ili upravljanje.

Menadžment kao nauka predstavlja univerzalno sredstvo savremenog sveta. Svako preduzeće ili sistem zahtevaju kontinuirano upravljanje da bi doveli do željenog cilja. Savremene organizacije i sistemi, zahtevaju stalne upravljačke akcije da bi delovali i razvijali se u složenom i dinamičkom okruženju u kome funkcionišu. Menadžment je neophodan za efikasno funkcionisanje i razvoj svakog preduzeća, društvenog sistema i društva u celini, za efikasnije odvijanje svakog složenijeg posla i poduhvata, sledstveno tome i sistema odbrane.

Strategijski menadžment, kao specijalizovana menadžment disciplina koja je nastala sredinom 20. veka predstavlja novi moderan pristup upravljanju preduzećem i bavi se budućnošću preduzeća. Strategijskim menadžmentom ne definišemo ni početak ni kraj već proces kao trajanje, podložan promenama, a koliko uspešan to zavisi od znanja i sposobnosti nosilaca upravljačke (menadžment) funkcije. Postoje brojni pokretački faktori koji intenziviraju potrebu za strategijskom perspektivom i većim angažovanjem kako u okviru celokupnog društva tako i u njegovim složenim sistemima. Neki od najznačajnijih faktora koji su doveli do evolucije strategijskog menadžmenta su: globalizacija, tehnologija i intelektualni kapital.

* Potpukovnik sci Antonio Mak je student doktorskih studija u Vojnoj akademiji; studijski program: Menadžment u odbrani. 
Sistem odbrane kao poseban podsistem, sistema nacionalne bezbednosti predstavlja plodno tlo za primenu različitih menadžment disciplina, pa tako i strategijskog menadžmenta. Primena i razvoj menadžmenta kao delatnost i veština se prevashodno razvio za potrebe sistema odbrane, a potom su njegovi principi bili preuzeti od strane drugih sistema u društvu, koji su ga kroz istoriju razvijali uključujući i razvoj specijalizovanih menadžment disciplina kakva je i strategijski menadžment, da bi potom ponovo našli primenu kako u svim oblastima života tako i okviru sistema odbrane.

Rad se sastoji iz tri pitanja koja daju jedinstvenu sliku o istorijskim okolnostima koje su vremenom kroz evoluciju menadžmenta kao delatnosti, dovele i do nastanka zasebne naučne discipline i teorije koja nastavlja da koegzistira i da se razvija sa menadžmentom kao delatnošću. Nastavljajući praćenje razvoja menadžmenta koja je dovela i do nastanka strategijskog menadžmenta kao specijalizovane menadžment discipline koja je svoju primenu našla i u sistemima odbrane mnogih zemalja počevši od OS SAD tokom 1962. godine, pa do primene u sistemu odbrane Republike Srbije od 2009. godine. Esenciju rada predstavlja prezentovanje istorijske geneze strategijskog menadžmenta sa posebnim osvrtom na primenu ove menadžment discipline za potrebe sistema odbrane Republike Srbije.

U prvom pitanju težište je dato na pojmovnom objašnjenju strategijskog menadžmenta, odnosno razvoju menadžmenta kao preteče strategijskog menadžmenta; prvo kao praktične delatnosti, a potom i kao naučne discipline. Razvoj menadžmenta kao nauke, a samim time i razvoj strategijskog menadžmenta, posmatran kroz prizmu 3 vremenska okvira, i to: (1) od 1880. godine do kraja Drugog svetskog rata, (2) od kraja Drugog svetskog rata do kraja 20. veka i (3) od kraja 20. veka do danas, objašnjen je u drugom pitanju. Specifičnost primene strategijskog menadžmenta u sistemu odbrane Republike Srbije objašnjena je pomoću jednog od svojevrsnih alata za pragmatičnu primenu strategijskog menadžmenta, i to pomoću sistema planiranja, programiranja, budžetiranja i izvršenja; što ujedno predstavlja i problematiku trećeg pitanja.

\section{Pojam strategijskog menadžmenta}

Strategijski menadžment je termin koji se u menadžmentu, organizacionoj teoriji i praksi koristi gotovo svakodnevno. Međutim iako je relativno često u upotrebi, značenje tog pojma još uvek nije precizno i jednoznačno određeno. Uopšteno predstavlja noviji model i moderan pristup upravljanja preduzećem, koji podrazumeva kontinualan proces stalnog prilagođavanja preduzeća promenljivoj okolini, u kome okolina vrši stalan uticaj na preduzeće, dok i samo preduzeće vrši uticaj na okolinu. Uvodi pojam strategije u menadžment kao način rešavanja budućih stanja i problema, kao svojevrsnog vodiča preduzeća u budućnost. Smatra se da na pojavu strategijskog menadžmenta dve velike grupe faktora i to: (1) sve veće promene, iskušenja i dinamičnost okruženja i (2) razvoj i usavršavanje metoda ${ }^{1}$ i tehnika procesa upravljanja.

\footnotetext{
${ }^{1} \mathrm{U}$ okviru ove grupe faktora treba pomenuti razvoj metoda i tehnika procesa upravljanja kao što su: metodi dugoročnog planiranja, sitem PPB (planiranje, programiranje i budžetiranje), kriva iskustva, SWOT analiza, analiza scenarija, breinstorming, analiza jaza itd.
} 
Strategijski menadžment predstavlja novi, moderan pristup upravljanju preduzećem, koji podrazumeva kontinualan proces stalnog prilagođavanja preduzeća promenljivoj okolini, u kome okolina vrši permanentan uticaj na preduzeće, a samo preduzeće, takođe, vrši određeni uticaj na okolinu u kojoj egzistira i kojoj se prilagođava. ${ }^{2}$

U dostupnoj literaturi autori se najčešće bave strategijskim menadžmentom kao procesom. Da bi se strategijski menadžment mogao razmatrati i sa aspekta njegove naučne utemeljenosti korisno je, prethodno, za potpuno razumevanje značenja pojma strategijski menadžment sagledati i saznanja o tom pojmu u dostupnoj literaturi odrediti nominalno značenje pojma strategijski menadžment.

Neki autori definišu strategijski menadžment krajnje jednostavno kao upravljanje preduzećem u uslovima promena. Reč je o konceptu upravljanja koji nastaje u uslovima velikih promena i koji pomaže menadžerima da identifikuju ključne faktore u spoljašnjem i unutrašnjem okruženju organizacija, kako bi pravilno formulisali najuažnije odluke, pre svih ciljeve i strategije radi obezbeđivanja uspeha svojih organizacija.

U Leksikonu menadžmenta, profesor Petar Jovanović, pod terminom strategijski menadžment podrazumeva se specijalizovana disciplina menadžmenta koja podrazumeva kontinualan procesualnog prilagođavanja preduzeća promenljivoj okolini, u kojem okolina vrši permanentan uticaj na preduzeće, a samo preduzeće, takođe, vrši određeni uticaj na okolinu u kojoj egzistira i kojoj se prilagođava. Strategijski menadžment obuhvata utvrđivanje i definisanje ciljeva preduzeća, određivanje strategije preduzeća, zatim proces realizacije definisane strategije i kontrolu realizacije i dobijenih rezultata. ${ }^{4}$

Strategijski menadžment može se odrediti kao proces upravljanja organizacionim sistemima i poslovima posredstvom strategije, kao specifičnim načinom za ostvarivanje utvrđenih (dugoročnih) ciljeva. Stiven Robins i Meri Kolter smatraju da je strategijski menadžment ono što menadžeri rade kako bi razvili organizacionu strategiju. Pod organizacionom strategijom podrazumevaju odluke i akcije koje određuju dugoročne performanse organizacije. ${ }^{5}$

Fred Dejvid definiše strategijski menadžment kao veštinu i nauku formulisanja, primene i ocene među funkcionalnih odluka koje omogućuju organizaciji da ostvari svoje ciljeve. Fokus strategijskog menadžmenta je na objedinjavanju različitih poslovnih funkcija i sistema radi postizanja uspeha. ${ }^{6}$ Dejvid koristi termine strategijski menadžment i strategijsko planiranje kao sinonime, ističući da se prvi češće upotrebljava u svetu biznisa, a drugi u akademskoj zajednici. ${ }^{7}$

Samjuel i Trevis Kerto pod strategijskim menadžmentom podrazumevaju proces kojim se obezbeđuje da organizacija poseduje i ostvaruje koristi iz odgovarajuće organizacione strategije. Odgovarajuća strategija, prema mišljenju autora, jeste ona koja je najbolje prilagođena organizacionim potrebama u konkretnom vremenu.

\footnotetext{
${ }^{2}$ Jovanović P., Strategijski menadžment, Zuhra, Beograd, 2007, str. 11.

${ }^{3}$ Erić, D., Uvod u menadžment, Čigoja štampa, Beograd, 2000, str. 334.

${ }^{4}$ Isto, str. 295.

${ }^{5}$ Robbins, S., Coulter, M., Management, 9th ed., Pearson Prentice Hall, New Jersey, 2009, pp. 208

${ }^{6}$ David, F., Strategic management: concepts and cases, 11th ed., Pearson Prentice Hall, New Jersey, 2007, pp. 5.

7 Termin strategijsko planiranje nastao je 50-ih godina prošlog veka i bio je veoma popularan između sredine šezdesetih i sredine sedamdesetih godina. Mnoge kompanije, posebno u SAD, smatrale su da je strategijsko planiranje odgovor za sve probleme u organizaciji.

${ }^{8}$ Certo, S., Certo., T., Modern Management: Concepts and Skills, 11th ed., Pearson Prentice Hall, New Jersey, 2009, pp. 228
} 
Navedene akademske definicije ukazuju na različite pristupe autora u određivanju značenja pojma strategijski menadžment. Zajedničko stanovište većine autora je da strategijski menadžment predstavlja proces koji se tiče organizacione strategije, kao načina za dostizanje dugoročnih ciljeva, odnosno performansi organizacije.

$\mathrm{Na}$ osnovu izvršene analize dostupne literature u kojima se na neposredan ili posredan način govorio značenju pojma koji je određen tom sintagmom, strategijski menadžment se može definisati kao posebna (specijalizovana) naučna disciplina menadžmenta koja razmatra proces formulisanja i implementacije strategije radi ostvarivanja dugoročnih ciljeva organizacije. Strategijski menadžment se sastoji od analiza, odluka i aktivnosti koje neka organizacija preduzima kako bi stvorila i zadržala konkurentske prednosti. ${ }^{9}$ Postoje četiri ključna atributa strategijskog menadžmenta koji podrazumevaju: (1) ciljeve organizacije, (2) brojne stejkholdere, (3) kratkoročne i dugoročne ciljeve i balans između efektivnosti i efikasnosti. Ako posmatramo razvoj menadžmenta, a samim tim i strategijskog menadžmenta kao specijalizovane discipline menadžmenta kroz istoriju, potrebno je da napravimo razliku između menadžmenta kao prakse i menadžmenta kao nauke. Kao praksa, menadžment je veoma star proces, dok je kao naučna disciplina znatno mlađi.

\section{Geneza strategijskog menadžmenta kao delatnosti}

Menadžment kao metod, veština upravljanja ili delatnost vuče svoje korene još od nastanka ljudskog društva. U prvobitnoj zajednici čovek je u neprekidnoj borbi sa prirodom, svoj rad i određene najjednostavnije poslove i aktivnosti obavljao intuitivno. Kasnije je, poučen prethodnim iskustvima, počeo da planira i organizuje te aktivnost kako bi ih što efikasnije obavio ili ostvario prethodno zacrtane ciljeve. Zato se i tvrdi da je upravljanje kao složena aktivnost stara koliko i sama ljudska civilizacija. Prvi pisani tragovi o menadžmentu vezani su za upravljanje javnim radovima, određenim državnim i vojnim aktivnostima, odnosno crkvenim delatnostima i vezani su za najstarije organizacije kakve su država, crkva i vojska.

Menadžment kao delatnost posmatraćemo u svetlu istorijskog razvoja misli o menadžmentu koji je svo vreme pratio ljudsku aktivnost i upravljanje kroz usložnjavanje odnosa međuljudske interakcije u cilju bolje zaštite zajedničkih interesa i gomilanja kapitala. Kao karakteristični periodi kroz koje ćemo posmatrati izdvajaju se rani (nascentni ${ }^{10}$ ) menadžment, menadžment u srednjem veku, dok je značajno potrebnu pažnju posvetiti i uticaju industrijske revolucije na menadžment, čime se praktično stvaraju uslovi i za razvoj menadžmenta kao naučne discipline i teorije, što je kasnije uslovilo i pojavu i strategijskog menadžmenta.

Evolucijom grupa od porodica do nacije otvorilo se pitanje autoriteta u organizaciji. Dok je u familiji ovaj problem rešavan veoma jednostavno, a u zavisnosti od toga da li se radi patrijarhatu ili matrijarhatu, na nivou države pojavio se konflikt između podređenih i nadređenih. Zbog tog sukoba, pojavila se ideja o kralju, ili bolje reći božanskom kralju, jer je kralj postao kraljem tek kada ga postavi sveštenik. Jedan takav kralj bio je i Vavilonski kralj Hammurabi (2123 - 2081 g. p.n.e.) koji je pravo da vlada, kao i njegov poznati Hamurabijev

\footnotetext{
${ }^{9}$ Dess, Lumpkini Eisner, Strategijski menadžment, Data Status, Beograd,2007, str. 5.

${ }^{10}$ Erić, D., Uvodumenadžmenta, Čigojaštampa, Beograd, 2000, str. 94-100.
} 
zakonik, dobio od kralja sunca. Vavilon, blizu modernog Bagdada, između reka Tigris i Eufrat možemo smatrati kolevkom moderne civilizacije. ${ }^{11}$ Već pomenuti zakonik je sadržao 282 pravila koja su regulisala državne poslove, lično ponašanje, međuljudske odnose, plate, kazne i dr. Pojedine odredbe su bile veoma stroge, tako da je čak predviđena smrtna kazna za graditelje čija bi se građevina srušila i pri tome usmrtila vlasnika građevine.

Severno i zapadno od Vavilona nalazila se Mesopotamija gde je crkva razvila jedan rani koncept „,korporacije” ili bolje reći ,,grupu crkava” koje su bile pod upravom opšteg menadžmenta. Naime, oko 3000. g. p.n.e. upravljanje crkvom zasnivalo se na dualnom sistemu: jedan deo visokog sveštenstva je bio odgovoran za ceremonijalne i religijske aktivnosti, dok se drugi deo bavio koordinacijom javnih aktivnosti.

Kao i u mnogim drugim segmentima ljudskog stvaralaštva Kina je nezaobilazna kada se utvrđuje geneza razvoja pojedinih oblasti. $U$ tom kontekstu ni menadžment misao nije izuzetak. Spomenuli smo već da vojska kao organizacija predstavlja jednu od ljudskih tvorevina u kojoj se javljaju prvi počeci menadžmenta. U tom smislu interesantno je spomenuti Kineskog generala Sun Tzu koji se smatra piscem najstarijeg spisa o menadžmentu u vojsci. ${ }^{12}$ On je pisao o organizaciji armije na niže sastavne delove, nivoima oficira u hijerarhiji, upotrebi zastava, gongova, i vatre u komunikaciji i sl. Najznačajnije je, međutim, a sa aspekta razvoja menadžment misli, u tom spisu to što on govori o planiranju kao neizostavnom segmentu u toku pripreme vojnih operacija ukoliko se želi ostvariti pobeda. U navedenoj literaturi su poznata dva njegova stava o planiranju i izvršavanju zadataka postavljenih od strane viših upravljačkih nivoa (general koji želi da dobije bitku mora da planira operaciju pre bitke, i general koji sluša njegove biće pobednik).

Za razliku od Sun Tzu kod koga nalazimo prve začetke saznanja o potrebi planiranja, kao bitnog segmenta procesa menadžmenta, i poštovanja hijerarhijskog položaja, kod Konfučija, u čije vreme je u Kini veoma cenjen posao bio u državnoj službi, dok su trgovci bili samo malo na višem nivou društvenih vrednosti od osuđenika, nalazimo početke razmišljanja o onome što bismo danas zvali nagrađivanje i kadrovska politika. Ideje koje je Konfučije izneo u svojim spisima, potreba proveravanja ljudi i ocenjivanje njihovog rada pre prijema u državnu službu, realizovane su 270 godina nakon njegove smrti, kada se ,,...za vreme vladavine dinastije Han (od 206. g.p.n.e. do 220 g.) počelo s proverom vrednosti kandidata za državnu službu, prema savetima koje dao Konfučije. Vrednost kao osnova za izbor na položaj dovela je, sa svoje strane, do određivanja vrednosti (do procene uspešnosti obavljanja poslova) kao osnova za unapređivanje."13

Pored toga, međutim, Kina je imala velike probleme sa državnom administracijom, jer se pokazalo da selekcija kadrova na osnovu klasičnih učenih kvaliteta ne donosi nužno najbolje rezultate. Naime, velika korupcija, i manipulacije sa službenicima bile su povod mnogobrojnim pokušajima reformi u državnoj upravi. Kineska birokratija je u potpunosti bila razvijena oko 1000. g.p.n.e., tj. oko 500. g., pre Konfučija čija je filozofija bila u suprotnosti sa tadašnjim legalistima koji su kroz sistem nagrada i kazni, u pravnom sistemu, nastojali da obezbede funkcionisanje sistema. Nasuprot legalistima, Konfučije se zalagao za poboljša-

\footnotetext{
${ }^{11}$ Vasić Ž., Sajfert D., Jevremović M., Osnovi menadžmenta, Visoka škola elektrotehnike i računarstva strukovih studija, Beograd, 2013, str. 20.

${ }^{12}$ Ilić B., Menadžment, Fakultet za trgovinu i bankarstvo, Inegraf, Beograd, 2002., str. 49.

${ }^{13}$ Wren, D.A., Vioch, D., Menadžment, proces struktura i ponašanje, Privredni pregeld - Grmeč, Beograd, 1994, str. 47.
} 
nje i unapređenje moralnih vrednosti kod ljudi kako bi obezbedio saradnju. Ovaj detalj pokazuje koliko je star sukob između formalista i humanista. Pored toga postoje dokazi da su Kinezi poznavali podelu rada, i departmanizaciju u organizacijama. U državnim radionicama za proizvodnju činija za rižu postojao je, naime, visok stepen podele rada i one su bile podeljene na odeljenja za računovodstvo, bezbednost i proizvodnju.

Slične ideje kao i kod Konfučija nalazimo u Indiji gde se Chanakya Kautilya zalagao i pisao o potrebnim kvalifikacijama za državnu službu između kojih izdvajamo porodično poreklo, obdarenost mudrošću, elokvencija, inteligencija, entuzijazam, društvenost i slično. Osim toga on je pisao o potrebi departmanizacije, nužnosti detaljne pripreme posla i drugo.

Drevni Egipćani su razvili obimne irigacione projekte kao odgovor na periodične poplave Nila, te ogromne sisteme kanala, kao i naširoko poznate piramide. Mnogi od ovih projekta rađeni su u državnom aranžmanu i sasvim je logično da je za njihovo izvođenje bila neophodna dobro razvijena državna birokratija. Pored toga, bio je definisan i maksimalan broj izvršilaca koje kontroliše jedan nadzornik, danas bi to zvali obim menadžmenta, i iznosio je deset, pri čemu je bilo određena različita odeća za nadzornike i izvršioce. Ovo pravilo je bilo poznato u većem broju ranih civilizacija. Jedan od najstarijih termina koji se koristio da opiše ,,profesionalnu” menadžersku ulogu je vezir. Jedan od najpoznatijih vezira je bio Hebrej Josef, koji je zajedno sa svojim bratom bio prodan u ropstvo. Zbog njegove sposobnosti predviđanja faraon ga je postavio za vezira. Njegova kancelarija je tako bila jedna od prvih kancelarija, direktora, organizatora, koordinatora i donosioca odluka. Pod njim je razvijena birokratija koja je merila visinu Nila od koje je zavisio svaki deo nacionalne ekonomije, prognozirala obim žetve, alocirala državne prihode, i nadgledala celokupnu državnu proizvodnju i trgovinu. Ovde je moguće pronaći, za to vreme, veoma napredne sofisticirane metode upravljanja pomoću predviđanja, planiranja posla, podele rada i uspostavljanja ,,profesionalnog” administratora čiji je isključivi zadatak bio da koordinira i kontroliše državne poslove.

Institucije, umetnost, jezik, drama i literatura starih Grka predstavlja značajan deo kulture celokupnog čovečanstva. Međutim, Grčka ekonomska filozofija je bila antiposlovna, tako da je trgovina predstavlja nešto što je ispod dostojanstva Grčkih ideala, te je bila ignorisana od strane aristokratije i namenjena manje cenjenim građanima. Čuveni grčki filozof Sokrat se bavio opservacijama menadžerskih veština koji se prenose sa privatnih na javne poslove. ${ }^{14}$

Uprkos anti-poslovnoj filozofiji koja je dominirala u staroj Grčkoj neophodno je reći da je u to vreme posejano seme demokratije, da su učinjeni prvi pokušaji u decentralizaciji upravljanja državom i pokušaj ustanovljenja individualnih sloboda. Sa aspekta evolucije menadžment misli potrebno je istaći da su učinjeni prvi pokušaji korišćenja naučnog metoda za rešavanje problema podele rada, departmanizacije, delegiranja i vođstva.

Rimljani su razvili jedan ,,kvazi fabrički” sistem za proizvodnju ratne opreme za njihove legije, zatim za izradu grnčarije, a posle i tekstila koji se izvozio. Pored toga, poznat je i sistem puteva izgrađen za distribuciju robe, kao i za što je moguće brže pokrete vojnih trupa do udaljenih kolonija. Rast i razvoj međunarodne trgovine zahtevao je trgovačku standardizaciju tako da je država razvila garantovani sistem mera za težinu i kovani novac. Država je regulisala sve aspekte ekonomskog života. Osim toga, rimsko pravo postalo je model za kasnije civilizacije.

\footnotetext{
${ }^{14}$ Talijan, M., Bezbednosni menadžment u suprostavljanju terorizmu i borbi protiv terorizma, Medija centar „Odbrana“, Beograd, 2012., str. 110.
} 
Zbog širenja hrišćanstva na srednji istok crkva se suočila sa velikim organizacionim problemima. Rane kongregacije su delovale nezavisno, pri čemu je svaka od njih definisala sopstven doktrine i uslove za članstvo. , U drugom veku naše ere, vođe su shvatile da je potrebno strože definisati ciljeve, doktrine i vođenje hrišćanskih aktivnosti, kao i uslova za članstvo u organizaciji. Kao rezultat svega toga nastala je religijska organizacija i centralizovani izvor autoriteta u ličnosti Pape." ${ }^{15}$ Modernim menadžment terminima rečeno vođe rimokatoličke crkve su opazili potrebu za institucionalizacijom organizacije i potrebom za definisanjem politike, procedura, doktrina i autoriteta.

$U$ periodu pre industrijske revolucije izrada proizvoda se vršila uglavnom za porodične potrebe, dok su se ostali proizvodi izrađivali u gildama koje su, koliko je poznato, egzistirale u periodu od 1110. do 1500. g. Poznata su bila dva tipa gildi i to: (1) trgovačke i (2) zanatske. U zanatskim gildama su bili proizvođači dobara, U njima je postojala hijerarhija autoriteta u tri nivoa: (a) majstori, (b) zanatski pomoćnici (kalfe) i (v) šegrti. Pored toga bila je izvršena stroga podela tako da su pravila gilde zabranjivala zanatlijama određenog profila da se bave izradom proizvoda koji nisu njihove struke. Trgovačke gilde su predstavljale preteču modernih trgovačkih asocijacija. Trgovci su kupovali sirovine i repromaterijal i prodavali ih proizvođačima od kojih su otkupljivali gotove proizvode. Rast trgovine posledično je doveo do nastanka računovodstva.

Ukupno uzevši ekonomija kao delatnost i misao o delatnosti je u periodu ,,srednjeg veka" bila sterilna. $U$ to vreme se smatralo da su jedina dva faktora proizvodnje rad i zemlja, a kapital je kao faktor proizvodnje omalovažavan. Istovremeno, međutim, nije poznata ni jedna ideja o tome da je menadžment neizostavan ulazni elemenat proizvodnje.

$\mathrm{Na}$ ovaj period nadovezuje se 16. i 17. vek koje su obeležila otkrića novih zemalja, novih trgovačkih puteva, kreiranje novih proizvoda i nastanak međunarodnog tržišta, a što se ekonomske misli tiče on je obeležen nastankom i dominacijom merkantilizma. $\mathrm{Na}$ prvim stepenicama industrijske revolucije pojavilo se učenje koje preferiralo slobodno tržište, privatnu inicijativu, interes pojedinca u odnosu na državni interes.

Sumiramo li prethodno rečeno, o razvoju menadžment misli u periodu pre industrijske revolucije, vidimo da su njome dominirale kulturne vrednosti koje su uglavnom bile antiekonomske, i nehumane. U to vreme ekonomije i društva su bili zatvoreni i statični, a u političkom smislu period je okarakteriziran centralizacijom vlasti u jednom autoritetu. Pojedine, rane ideje o menadžmentu koje su se pojavljivale bile su ograničeni na lokalni nivo i nisu se širile.

\section{Strategijski menadžment kao naučna disciplina}

Istorijski posmatrano, industrijalizacija predstavlja relativno noviji fenomen. Čovečanstvo je, naime, vekovima egzistiralo i pre pronalaska energije, transporta, komunikacija i tehnologije, tj. dostignuća industrijske revolucije. Širenje ideja velikih mislilaca omogućeno je pronalaskom i usavršavanjem štamparije, čime su se stvorili uslovi za industrijsku revoluciju i prelazak iz neindustrijskog u industrijsko društvo. Kvalitativan napredak koji je industrijska revolucija omogućila sastojao se u zameni ljudske, životinjske ili neke druge energije mašinskom.

${ }^{15}$ Isto, str.47. 
U tom kontekstu posebno mesto zauzima pronalazak i dugogodišnje usavršavanje parne mašine od strane Džejmsa Vata ${ }^{16}$. Širenje primene i korišćenja parne mašine imalo je značajne ekonomske posledice. U prvom redu neophodno je istaći da je kontinuirano snižavanje cene parne energije omogućilo njenu primenu u proizvodnji i transportu što je omogućilo povećani obim proizvodnje i širenje tržišta. Pored toga, duh inovacija je vodio novim pronalascima, oni novim fabrikama, a nove fabrike stvarale su potrebu za organizacijom i upravljanjem.

$U$ teorijskom pogledu, pre industrijske revolucije egzistirala su različita shvatanja o broju faktora proizvodnje. U jednom periodu se smatralo da egzistiraju dva faktora proizvodnje, zemlja i rad, dok je kapital kao neophodan input priznat tek kada je nestala crkvena zabrana. Žan Baptist Sej je, međutim, bio prvi koji je eksplicitno priznao postojanje četvrtog faktora proizvodnje. Pri tome on navodi pojedince koji preduzimaju određene poslovne poduhvate posuđujući resurse od drugih ili čineći partnerstva. Za uspešno realizaciju poduhvata, navodi Sej oni moraju zaposliti veći ili manji broj radnika, nabaviti sirovine i repromaterijal, pronaći kupce, pri čemu neprekidno postoji određeni stepen rizika da poduhvat propadne. Nagrada za preuzet rizik u kombinovanju faktora proizvodnje je u obliku povećanog povrata investiranog kapitala. U početnom periodu ove evolucije preduzetnik je bio inovator isto toliko koliko i menadžer. Sej je posebno isticao veliki značaj preduzetnika i preduzetništva. ${ }^{17}$

Rastom njegove organizacije preduzetnik je došao u situaciju da više ne može sam upravljati i kontrolisati sve neophodne aktivnosti, te je počeo delegirati ovlašćenja pojedinim svojim saradnicima. Ti ljudi su bili podmenadžeri prvi ,,nevlasnici”, tj. plaćena lica koja su imala odgovornost za odluke koje donose u okviru šire poslovne politike koju je zacrtao preduzetnik. Ovo je veoma bitan trenutak, jer ga karakteriše kvalitativna promena, ili bar njene prve naznake, tj. razdvajanje funkcije vlasništva od funkcije upravljanja. Ovakva situacija rezultirala je nastankom različitih shvatanja menadžera i preduzetnika. Razlike između ovih pogleda se mogu identifikovati u tome da su pojedini autori smatrali da preduzetnik donosi strateške odluke kojima širi konkurentsku politiku celokupne firme, dok menadžer donosi taktičke odluke, u okviru te politike.

Nastankom fabričke proizvodnje pojavili su se, do tada, nepoznati problemi iz sfere menadžmenta. Crkva je organizovala i upravljala svojim imanjima zahvaljujući dogmi i veri, vojska je kontrolu velikog broja ljudi vršila kroz rigidnu hijerarhiju, disciplinu i autoritet, a državna uprava je funkcionisala bez konkurencije. Za razliku od ovih organizacija, menadžeri u novom fabričkom sistemu nisu mogli da primene ni jedan od ovih principa da bi osigurali korišćenje resursa. Početak industrijalizacije kao posledica industrijalizacije doveo je do sve većeg ukrupnjavanja preduzeća u kontinuirano menjajućem konkurentskom okruženju.

Porastom organizacije smanjivala se mogućnost preduzetnika - vlasnika da nadgleda zaposlene i javila se potreba za jedan posredan nivo nadzora. Ovi nadzornici su regrutovani iz niže klase nego što je to bio preduzetnik i obično se radilo o nepismenim radnicima koji su pokazivali nešto više tehničke umešnosti ili umeća održavanja discipline. S obzirom da su bili plaćeni samo malo više od neposrednih izvršioca bili su slabo motivisani. Tadašnji

\footnotetext{
${ }^{16}$ Erić, D., Uvod u menadžment, Čigoja štampa, Beograd, 2000, str. 100.

${ }^{17}$ Isto, str101.
} 
opšti pogled na upravljanje svodio se na to da uspešnost u upravljanju zavisi od karaktera upravljača, njegovih ličnih osobina i temperamenta, a ne od opštih koncepata upravljanja. Određenja unapređenja u ovom pogledu donelo je korišćenje drugog izvora za regrutovanje upravljačkog sloja. Preduzetnici su, naime, često postavljali svoje rođake na upravljačke pozicije, smatrajući pri tome da će oni nastojati da sačuvaju svoje potencijalno nasleđe.

Džejms Montgomeri je, verovatno, autor prvog teksta o upravljanju. Njegovi su upravljački saveti bili u velikoj meri tehničke prirode. Odnosili su na to kako prepoznati kvalitet i kvantitet rada, kako prilagoditi i popraviti mašine, kako održavati troškove na niskom nivou. Pored toga, on je savetovao menadžere da moraju biti pravedni i nepristrasni, čvrsti i odlučni, te da stalno moraju biti spremni da spreče nastajanje greške. Ovo je veoma bitno jer je iz toga vidljivo da je on kontrolnu funkciju smatrao kao aktivnost koja je okrenut napred a ne nazad. Slično mnogim autorima, Montgomeri nije nastojao da razvije opšte principe upravljanja, već se ograničio samo na pamučnu industriju. On je bio uvažavan kao menadžer, te 1836. godine pozvan u SAD na mesto upravnika u firmu ,,Jork Mils”, što mu je dalo mogućnost da uradi, verovatno, prvu komparativnu studiju menadžmenta različitih ekonomija. Analizirajući cene gotovih proizvoda, sirovina i visinu najamnina, on je zaključio da su engleske firme $u$ to vreme bile bolje vođene $u$ odnosu na istovrsne u SAD.

lako su se raznovrsne upravljačke aktivnosti neprekidno koristile tokom duge ljudske istorije, menadžment se zbog raznih okolnosti, relativno kasno razvio kao naučna disciplina. lako menadžmenta kao veštine egzistira od davnina, menadžmenta kao nauka nastaje početkom dvadesetog veka. ${ }^{18}$ Među prvim autorima tzv. ,,pionira menadžmenta"koji je sistematski proučavao menadžment i koji se smatra tvorcem menadžmenta kao nauke jeste Frederik Tejlor. Značajan doprinos nastanku i razvoju menadžmenta dao je i francuski teoretičar Anri Fajol, kao i mnogi drugi. ${ }^{19}$ Menadžment pripada polju društveno-humanističkih nauka. Razvijao se kroz veći broj škola i pristupa pri čemu je razvoj ove naučne teorije najlakše pratiti kroz analizu i razmatranje ovih škola i pristupa discipline.

lako menadžment u savremenom smislu, nastaje u 19. veku uporedo sa pojavom industrijskih revolucija, pojavom industrijskih preduzeća, fabrika, naučno-tehničkog napretka, naučni pristup menadžmentu razvio se tek početkom 20. veka sa prvim radovima Frederika Tejlora i Anri Fajola. Značajno je i istaći da jedno vremen na početku uspostavljanja menadžmenta kao naučne discipline reči upravljanje i administracija korišćene su da označe isti pojam. Ovaj fenomen upravo potiče od Fajola koji je u tom periodu koristio reč administracija da bi označio pojam upravljanje-menadžment. ${ }^{20}$

Menadžment kao naučna disciplina bio je predmet izučavanja brojnih autora i istraživača koji su dali različit, ali i višestruki doprinos njegovom razvoju. Od pojave izučavanja menadžmenta kao nauke, pa do danas, razvilo se više pravaca (škola) menadžmenta. Možemo reći da su najvažniji sledeći pravci:

- Klasična škola menadžmenta

- Škola ljudskih odnosa (Teorija međuljudskih odnosa)

- Škola teorije odlučivanja (Bihevioristički pristup)

\footnotetext{
${ }^{18}$ Izvesni Henri Toun je prvi, još 1886. godine, izrazio potrebu za kreiranjem posebne menadžerske nauke.

${ }^{19}$ Značajan doprinos razvoju menadžmenta kao nauke dali su: Henri Gant, Maks Veber Meri Parker Folet Elton Majo, Daglas Mekgregor, Henri Mintzberg, Piter Draker i drugi.

${ }^{20}$ Jovanović P., Menadžmengt - teorija i praksa,Visoka škola za projektni menadžment, Beograd, 2007, str. 7.
} 
- Škola nauke o menadžmentu (Kvantitativni pristup)

- Škola teorije sistema (Sistemski pristup)

- Situaciona škola menadžmenta (Situacioni pristup)

Predmet menadžmenta su problemi upravljanja poslovima, poduhvatima i organizacionim sistemima. Menadžment je primenjena nauka i u tesnoj je vezi sa drugim naukama. Menadžment kao nauka obuhvata veći broj naučnih disciplina, gde svaka od njih istražuje specifičan segment predmeta menadžmenta. Strategijski menadžment je jedna od specijalizovanih i najrazvijenijih naučnih disciplina menadžmenta, nastao na temeljima menadžmenta koji se relativno kasno ustoličio kao naučna disciplina. Baš kao i svaka druga naučna disciplina strategijski menadžment obuhvata istovremeno i celokupan sistem znanja koji su doveli do njegovog nastanka, koji se i dalje razvija i kao specifična forma čovekove delatnosti i „kao delatnost koja se odvija u društvenoj zajednici uz korišćenje i stalno razvijanje metodoloških znanja i postupaka“. ${ }^{21}$

Po pravilu, da bi saznanje dospelo na nivo (stepena) naučnog, mora ispunjavati sledeće osnovne uslove: (1) da ima sopstveni predmet izučavanja, (2) da ima sopstvenu naučnu metodu, (3) da ima razvijenu sopstvenu teoriju i (4) da se jasno iskazuje korišćenjem odgovarajućeg jezika. ${ }^{22}$ Shodno prethodno navedenom, kao i svaka naučna disciplina strategijski menadžment mora imati svoj predmet istraživanja ${ }^{23}$, metode, teoriju i da poseduje specifičnu terminologiju.

Predmet strategijskog menadžmenta su, u užem smislu, problemi formulisanja i implementacije strategije organizacije. U širem smislu, predmet strategijskog menadžmenta su problemi ispitivanja organizacionog okruženja (spoljašnjeg i unutrašnjeg), postavljanja misije organizacije, određivanja temeljnih dugoročnih ciljeva organizacije, razvijanje strategije za ostvarivanje tih ciljeva, primene strategije i kontrola primene strategije i dobijenih rezultata. ${ }^{24}$

Metode strategijskog menadžmenta imaju veliki broj zajedničkih karakteristika sa metodama drugih nauka i naučnih disciplina, ali imaju i određene specifičnosti koje proizilaze iz karakteristika predmeta istraživanja. ${ }^{25} \mathrm{U}$ istraživanju problema formulisanja i implementacije organizacione strategije analizirajući metode po redu definisanom u Uvodu metodologiju ratne veštine koriste se filozofske metode (npr. konkretna dijalektička metoda), opšte naučne metode(npr. metoda modelovanja, komparativna metoda), posebne naučne metode (analiza-sinteza, indukcija-dedukcija, apstrakcija-konkretizacija, generalizacija-specijalizacija, definicija i klasifikacija) i pojedinačne (empirijske) naučne metode (metoda ispitivanja i metoda analize sadržaja).

\footnotetext{
${ }^{21}$ Grupa autora, Metodologija ratne veštine, skripta, Centar vojnih škola Beograd, 1996, str. 11.

${ }^{22}$ Isto, str. 18-19.

${ }^{23}$ Prema najopštijem postupku klasifikovanja nauke predmet izučavanja je jedan od tri osnovna kriterijuma, pored oštosti i uloge naučnog saznanja, Grupa autora, Metodologija ratne veštine, skripta, Centar vojnih škola Beograd, 1996, str. 15

${ }^{24}$ Stojković, D., Đurić N., Blagojević S., Povezanost strategijskog menadžmenta i nauka odbrane, Vojno delo , Beograd, 2011, 63/2, str. 8.

${ }^{25}$ Činjenica da postoji više od 2000 nauka i naučnih disciplina, a samo oko 40 razvijenih naučnih metoda, ukazuje da više nauka koriste iste metode koja se smatraju specifičnim metodama određene nauke, odnosno naučne discipline, jer iste metode primenjene na različite predmete istraživanja doživljavaju izvesnu transformaciju.
} 
Teorija, metode i jezik strategijskog menadžmenta zasnivaju se na teoriji, metodama i jeziku menadžmenta uopšte, uz uvažavanje specifičnih karakteristika predmeta strategijskog menadžmenta. U osnovi teorije strategijskog menadžmenta nalazi se pojmovno-kategorijalni aparat koji čine pojmovi i kategorije različitog nivoa opštosti i koji su sistemski uređeni, analogno procesima i sadržajima strategijskog menadžmenta. Teorija strategijskog menadžmenta sadrži i veliki broj stavova, ali su mnogi od njih hipotetički, što ukazuje na to da je teorija nedovoljno izgrađena i da predstavlja značajan izvor problema istraživanja. Principi i načela su, takođe, zastupljeni u teoriji strategijskog menadžmenta, pri čemu su principi naučno utemeljeniji i više obavezni za primenu, dok se načela zasnivaju na iskustvu. U teoriji strategijskog menadžmenta zakoni i zakonitosti još uvek nisu dovoljno zastupljeni, što ukazuje na to da je neophodan dodatni istraživački napor da se oni otkriju, odnosno izvedu i jezički formulišu.

Naučni jezik je takođe jedan od osnovnih konstitutivnih elementa strategijskog menadžmenta kao naučne discipline, jer je u neposrednoj funkciji predmeta i teorije. Naučni jezik strategijskog menadžmenta zasnovan je na književnom jeziku i u skladu je sa karakteristikama predmeta istraživanja. Čine ga različiti termini kojima se komunicira u naučnoj teoriji i praksi.

Izučavanje strategijskog menadžmenta u našoj zemlji započelo je dosta kasno u odnosu na razvijene zemlje. Promena društvenog i privrednog sistema uticala je, pored ostalog, da se otpočne sa sistematskim izučavanjem strategijskog menadžmenta. Početkom devedesetih godina objavljuju se prvi udžbenici iz strategijskog menadžmenta, organizuju se naučni skupovi iz te oblasti, a kao obavezan predmet izučava se na mnogim fakultetima. Strategijski menadžment je danas afirmisana naučna i nastavna disciplina kojom se bave i veliki broj naučnih radnika i istraživača.

\section{Razvoj strategijskog menadžmenta po fazama}

Obzirom da smo u prethodnim delovima rada pratili društvene okolnosti kroz najznačajnije istorijske periode koji su bili neophodni preduslovi za nastanak i razvoj strategijskog menadžmenta, faze njegovog razvoja u ovom poglavlja u posmatraćemo u periodu od formiranja menadžmenta kao naučne discipline i teorije. Hronološki gledano, a shodno primeni menadžmenta kao prevashodno upravljačke i pragmatične ljudske delatnosti, a sa stanovišta ovog rada genezu društevnih okolnosti koje su dovele do nastanka i razvoja strategijskog menadžmenta uslovno ćemo podeliti na tri faze. Prva je od začetaka formiranja menadžmenta kao naučne discipline i teorije do kraja Drugog svetskog rata, zatim razvoj strategijskog menadžmenta do kraja 20 . veka i savremeni razvoj strategijskog menadžmenta.

\section{Razvoj strategijskog menadžmenta do kraja Drugog svetskog rata}

Prvu fazu možemo podeliti na dva perioda od 1880. do 1930. godine, period koji se naziva i ,,doba prvih savremenih menadžera“. Karakteristika ovog perioda je enorman porast industrijske proizvodnje na bazi naučno-tehnoloških otkrića, i period kada vlasnici fabrika poveravaju kompletnu proizvodnju posebno obučenim ljudima koji zastupaju nji- 
hove interese - menadžerima. Usled velikog broja fabrika i porasta broja menadžera pojavila se potreba za obučavanjem, odnosno školovanjem menadžera, pa u ovom periodu nastaje i prva naučna teorija, odnosno klasična ili ,,naučna“ škola menadžmenta koja je imala više pravaca. Od 1900. godine u centru pažnje je razvoj i utvrđivanje industrijske strukture koja je stvorena tokom industrijske revolucije. ${ }^{26}$

U Engleskoj se 1907. godine, prvi put u modernoj istoriji pojavljuju profesionalni menadžeri, i to kao direktna posledica razdvajanja privatnog (najčešće porodičnog) vlasništva nad kompanijama od upravljačkih funkcija, odnosno vlasnici kompanija nisu više bili i menadžeri. Ovim činom vlasnik kompanije postaje poslodavac i upravljačkim strukturama i radnicima (zaposlenima). Industrijski odnosi i razvoj organizacione strukture poslovnih organizacija ubrzano su doveli do legitimizacije i legalizacije menadžmenta u pogledu vlasti, a samim time i moći. Sledstveno tome, nastaje „,doba menadžmenta“ koje traje i danas, ali specifikumom modernog menadžmenta se ogleda u dve stvari: (1) postojanje velikog broja pojavnih oblika menadžmenta, odnosno menadžment disciplina i (2) broj pojavnih oblika nije konačan, već se on uvećava u skladu sa pojavom inovativnih ljudskih delatnosti. $^{27}$

Drugi period je do 1930. do 1950. godine, u ovom periodu još uvek se osećaju uticaji ratnih užasa iz Drugog svetskog rata, pa se sledstveno tome javlja pojačano interesovanje za ljude i/ili grupe ljudi i radi se mnogo na motivaciji radnika. $U$ organizacionoj teoriji ovaj period se naziva i bihevioristički pravac, neoklasična škola ili ,,škola međuljudskih odnosa“. Manjak trajne i kapitalne potrošnje 30-tih godina, te racionisana potrošnja tokom drugog sv. rata, zamenjena je velikom ekspanzijom tokom 40-ih i 50-ih godina koju su pratile rastuća kupovna moć, novi proizvodi, nove tehnologije, niska nezaposlenost i visoka i kontinuirana stopa rasta. Paralelno sa ovim trendovima došlo je do rasta obima preduzeća, a što je zahtevalo integrisanje organizacionih napora sa perspektive top menadžmenta. Sa aspekta okruženja u kome su preduzeća delovala takođe dolazi do značajnih promena, a u prvom redu ovde mislimo na povećano mešanje države u ekonomski život kroz pravnu regulativu (dominacija kenzijanizma u ekonomskoj teoriji), povećanje uloge sindikata i sl. Sve ovo je pred menadžere stavilo zadatak uzimanja sve većeg broja varijabli u obzir pri donošenju odluka, a zbog sve kompleksnijeg okruženja u kome su preduzeća ostvarivala svoju misiju. Kao posledica tih procesa teoretičari menadžmenta su izvršili reorijentaciju svoje pažnje sa nivoa proizvodnje na teoriju opšteg menadžmenta. ${ }^{28}$

Šira tržišta, naprednije tehnologije, kompleksniji organizacioni oblici, narastajući resursi i potreba za sve većim brojem menadžera iziskivali su potrebom za opštom teorijom menadžmenta. Prethodno smo već istakli da se menadžment misao širila iz SAD-a ka drugim delovima sveta. U ovom kontekstu pravovremeni doprinos teoriji opšteg menadžmenta predstavljao je Storsov prevod Fajolovog dela „Opšti i industrijski menadžment”, 1949. godine. Nakon toga pojavljuje se plejada naučnika koji su na osnovu Fajolovih stavova vršili poboljšanja i prilagođavanja njegovih stavova izmenjenim uslovi-

\footnotetext{
${ }^{26}$ Todosijević R., Strategijski menadžment-teorijske postavke, Ekonomski fakultet Subotica, Univerzitet u Novom Sadu, Subotica, 2009, str. 89.

${ }^{27}$ Kovačević, N., Domjančić S., i Kovač M., Strategijski menadžment u vojnoorganizacionom sistemima, Vojno delo septembar-okotbar 2018, str. 268.

${ }^{28}$ Isto, str 239.
} 
ma. Tako npr. Njumen, čiji su osnovni elementi koncepta bili slični Fajolovim, daje doprinos u sferi poslovne politike, a pre svega u posmatranju ciljeva koji trebaju definisati mesto preduzeća u industriji, socijalnu filozofiju firme i da služe ustanovljenju opšte menadžerske filozofije kompanije. Interesantno je spomenuti da ovo njegovo zanimanje za ciljeve vremenski koincidira sa ustanovljenjem Drakerovog koncepta ,upravljanja pomoću ciljeva". Značajan rad, sa aspekta potrage za sistematskom osnovom menadžment znanja predstavlja navedena knjiga $\mathrm{H}$. Kunca i O'Donela koji su unapredili Fajolovu ideju o univerzalnosti menadžmenta pri čemu su smatrali da se pet osnovnih menadžerskih funkcija ne odvija datim redosledom, već da menadžeri, u praksi svih ovih pet funkcija obavljaju simultano.

Slično kao i u Prvom, tako je i u Drugom svetskom ratu došlo ujedinjavanja napora menadžera, vladinih službenika i naučnika, a u svrhu racionalnog rešavanja tako krupnih problema kao što su radarski sistemi, protivavionska artiljerija, bombardovanje Nemačke i slično. Jedna od najpoznatijih takvih grupa je delovala pod imenom ,,Bleketov krug” i bila je sastavljena od tri fiziologa, dva matematička fizičara, jednog astrofizičara, jednog oficira, jednog nadzornika, jednog opšteg fizičara i dva matematičara. Grupom je rukovodio P. Bleket, dobitnik Nobelove nagrade za fiziku i kopronalazač radara. Njihov zadatak je bio da multidisciplinarnim pristupom pomognu rešavanju kompleksnih problema vođenja rata i odbrambenih napora.

Kasnije je ustanovljeno da metod operacionih istraživanja, koji u stvari predstavlja primenu naučnog metoda i znanja za rešavanja kompleksnih problema, te uspostavljanje kvantitativne baze za odlučivanje, može biti apliciran i za druge, nevojne svrhe. Primena ovog metoda u industriji je, sasvim logično, započela u menadžmentu proizvodnje, a u svrhu rešavanja problema zaliha, terminiranja proizvodnje, kontrole kvaliteta, prinosa kapitala i slično. Na ovaj način došlo je do kvalitativne promene u menadžmentu. Naime, moderni menadžment je evoluirao od naučnog menadžmenta, od potrage za naukom u menadžmentu do nastojanja da se nauka primeni u menadžmentu. Tačka na kojoj se ova promena dogodila predstavlja trenutak kada se matematika i ostale nauke počinju koristiti za rešavanje vekovnog problema; optimalne alokacije oskudnih resursa u svrhu postizanja cilja.

$\mathrm{Na}$ osnovu iznetog možemo zaključiti da je osnovan karakteristika ovog dela masovna proizvodnja. Pri čemu je i centar menadžmenta i celokupne industrijske aktivnosti bio na razradi i usavršavanju mehanizama masovne proizvodnje $\mathrm{e}^{29}$, pri čemu je briga o strategijskim izazovima bila u drugom planu.

Paralelno sa sve većim korišćenjem kompjutera uvode se sledeće tehnike: linearno programiranje, teorija repova, teorija igara, transportni problem, Monte Karlo i dr. Ovo je omogućilo da se npr. kompetitivne strategije najbolje mogu razumeti pomoću teorije igara, prinos na kapital se mogao, pomoću kompjutera, simulirati korišćenjem teorije verovatnoće, dok su kvantitativni modeli omogućavali testiranje uticaja i posledica promene jedne ili više varijabli, pa i celokupnog modela. Pored prethodno navedenih tehnika značajno je napomenuti da su u periodu od 1956 -1958. g. razvijene i tehnike mrežnog planiranja, CPM i PERT. Imamo li ovo u vidu, kao i prethodno navedene ideje i stavove tako velikih mislilaca ove oblasti kao što su Fajol, koji se pored ostalog zalagao za korišćenje

\footnotetext{
${ }^{29}$ Todosijević R., Strategijski menadžment-teorijske postavke, Ekonomski fakultet Subotica, Univerzitet u Novom Sadu, Subotica, 2009, str. 90.
} 
„,više matematike”, i Gant, može se reći da bi njih dvojica bili veoma iznenađeni onim šta su nove kvantitativne tehnike učinile od njihovih ideja. Ukupno uzevši, možemo reći da moderna menadžment nauka predstavlja ponovno pojavljivanje vekovnog traganja za predviđanjem, planiranjem, vođenjem, ocenjivanjem i kontrolom. Traganje za kvantifikacijom, u svetlu evolucije menadžment misli, je u stvari pokušaj kvantifikovanja varijabli u industrijskim i organizacionim problemima sa ciljem poboljšanja ocenjivanja i kontrole izvođenja posla, kao i pokušaj konstruisanja apstraktnih modela koji trebaju reprezentovati realan svet, a sa ciljem testiranja uticaja promena određenih varijabli.

Značajan kamenčić u mozaiku menadžment misli pridodan je razvojem opšte teorije sistema i sistemskim pristupom proučavanju menadžmenta. Sintagmu ,,opšta teorija sistema” kreirao je biolog Ludvig fon Bertalanfi (1901-1972). On je smatrao da je moguće razviti sistematski, teorijski okvir za opisivanje odnosa u realnom svetu, te da različite naučne discipline imaju sličnosti koje bi se mogle razviti u „opšti model sistema”. Ono što je, po njegovom mišljenju slično u svim naukama je sledeće: 1. posmatranje celine ili organizma, 2. težnja sistema za postizanje ekvilibrijuma i 3. otvorenost svih sistema, tj, vršenje uticaj sistema na njegovo okruženje, i obratno. ${ }^{30}$

Na Bertalanfijevim idejama Kenet Boulding je gradio svoje stavove. On je, u stvari, nastojao da integriše Vinerovu kibernetiku sa informacionom teorijom Šenona i Vivera. Pored nastojanja za pronalaženjem ,,opšteg denominatora” Boulding je razvio devet nivoa sistema u svrhu njihove analize i to: 1. skelet (statičan); 2. satni mehanizam; 3. termostat; 4. ćelija; 5. biljka; 6. životinja; 7. čovek; 8. društvena organizacija; 9. transcendentalan.

\section{Razvoj strategijskog menadžmenta do kraja 20. veka}

Evolucija strategijskog menadžmenta ima svoje četiri etape ili prema jednom delu autora četiri koncepta: (1) osnovno finansijsko planiranje, (2) planiranje zasnovano na predviđanju, (3) strategijsko planiranje i (4) strategijski menadžment. Bitno je konstatovati da na menadžment preduzeća bitno utiče epoha.

Prva etapa je esencija strategijskog menadžmenta i trajala je od 1950. do 1960. godine, Nastanak strategijskog menadžmenta je bio uslovljen potrebama poslovne prakse, naročito u domenu finansijskog planiranja i budžetiranja, a ne razvoja teorijskog pristupa, odnosno unapređenja postojećih koncepata menadžmenta. Prvi radovi iz ove specijalizovane menadžment discipline bili su Strategija i struktura od Alfreda Čendlera iz 1962. godine i Strategija preduzeća Igora Ansofa iz 1965. godine. Težišni problem menadžera tog doba bila je koordinacija odluka i proces kontrole usled složenosti poslovnog okruženja i veličine preduzeća. Sledstveno tome, javlja se strategija kao najvažniji dokument planiranja, i bazira se, uglavnom, na petogodišnjim planskim dokumentima koji, u načelu, obuhvataju: (1) skup ciljeva, (2) prognozu finansijskih parametara (prihode, troškove proizvodnje, učešće na tržištu, zahteve tržišta i slično), (3) prioritete u proizvodnji i (4) rasporede i procene kapitalnih ulaganja.

\footnotetext{
${ }^{30}$ Von Bertalanffy L., General system theory, George Brayiller, New York, 1968.

${ }^{31}$ Todorović J., Đuričin D., Janošević S., Strategijski menadžment, Institut za tržišna istraživanja, Beograd, 2000 , str. 33.
} 
$\mathrm{Na}$ osnovu strategije kao dokumenta na kojem počiva menadžment i organizacija preduzeća, jedna nova specijalizovana menadžment disciplina dobija svoje ime, jer naposletku strategija je u svojoj esenciji zapravo bila, a to je uglavnom i danas, ideja menadžera. Većina organizacija je imala/ima adekvatne mehanizme za implementiranje ideja menadžera u određene strategije. Strategija preduzeća se definiše kao skup pravila odlučivanja i vodič koji vodi preduzeće u budućnost radi dostizanja budućih ciljeva preduzeća. Ovi skupovi pravila odlučivanja se odnose na ponašanje preduzeća u promenjivoj okolini. ${ }^{32}$ Evolucija strategijskog menadžmenta se u velikoj meri poklapa sa razvojem pristupa u definisanju strategije.

Osnovna obeležja ove etape već smo istakli da strategijski menadžment uvodi pojam strategije kao načina za rešavanje budućih situacija i problema, kao svojevrsnog vodiča preduzeća u budućnost. Strategijski menadžment se bavi budućnošću preduzeća, njegovom pozicijom i poslovanjem i podrazumeva definisanje ciljeva koje preduzeće želi u budućnosti dostići i pravce i načine dostizanja ovih ciljeva, što i predstavlja strategiju." Sadržaj i funkcije strategijskog menadžmenta Strategijski menadžment je proces u kojem participira celokupna organizaciona struktura na svim nivoima, pa sledstveno tome dolazi do definisanja ili formiranja više strategija kojima se žele postići rezultati različitog značaja, u zavisnosti od kriterijuma i načina (metoda) definisanja.

Druga etapa je trajala od 1960. do 1970. godine i osnovno obeležje je dugoročno planiranje i kreiranje dugoročne poslovne politike. Centralna tema u ovoj etapi je bila diversifikacija u korporativnom planiranju. Osnovni nedostatak je bio striktno pridržavanje planovima, odnosno definisanim ciljevima, čije je ostvarenje u velikoj meri zavisilo od finansijskih uspeha, odnosno neuspeha, a kako u to vreme nije postojala adekvatna kontrola planova na nivou organizacije, planiranje se lociralo isključivo na nivou top menadžmenta, odnosno ovde započinje primena jednog od pristupa u planiranju - ,,odozgo na dole".

Treća etapa nastaje na bazi dugoročnog planiranja, ali se fokusira na analizu okruženja i donošenje odluka koje će uvažiti identifikovane rizike i neizvesnosti koje nosi budućnost. Strategijsko planiranje je nastalo iz potrebe za aktivnim reagovanjem na promene u okruženju. Treća etapa je trajala od 1970. do 1990. godine. ,Za razliku od koncepata dugoročnog planiranja, strategijsko planiranje je kompleksniji proces, jer zahteva više vremena i uključuje sagledavanje tržišnih, društveno-političkih, pravnih, ekonomskih, socijalnih i tehnoloških uslova, kao i izvora koji vode specifičnim mogućnostima i opasnostima u okruženju. Iz tog razloga, u proces stvaranja strategijskih planova organizacije i definisanje pravaca akcije neophodno je uključiti analizu informacija iz eksterne i interne sredine."

Strategija preduzeća se definiše kao skup pravila odlučivanja i vodič koji vodi preduzeće u budućnost radi dostizanja budućih ciljeva preduzeća. Ovi skupovi pravila odlučivanja se odnose na ponašanje preduzeća u promenjivoj okolini. ${ }^{33}$ Evolucija strategijskog menadžmenta se u velikoj meri poklapa sa razvojem pristupa u definisanju strategije. U Tabeli 1 prikazana je evolucija strategije shodno dominantnim temama. ${ }^{34}$

\footnotetext{
${ }^{32}$ Ansoff, H., I., Corporate Strategy, Penguin Books, London, 1987, p. 83.

${ }^{33}$ Abid, p. 121.

${ }^{34}$ Grant, R., Contemporary Strategy Analysis, VI Edition, Blackwell Publishing, Oxford, 2007.
} 
Tabela 1 - Razvoj strategije sa dominantnim temama

\begin{tabular}{|c|c|c|}
\hline Vreme trajanja strategije & Naziv strategije & $\begin{array}{c}\text { Dominantene teme u okviru } \\
\text { strategije }\end{array}$ \\
\hline 1950-1960. & $\begin{array}{l}\text { FINANSIJSKO } \\
\text { BUDŽETIRANjE }\end{array}$ & $\begin{array}{l}\text { 1. Finasijako planiranje i kontrola; } \\
\text { 2. Procena kapitalnih ulaganja } \\
\text { putem diskontovanja }\end{array}$ \\
\hline 1960-1970. & $\begin{array}{l}\text { KORPORATIVNO } \\
\text { PLANIRANjE }\end{array}$ & $\begin{array}{l}\text { 1. Srednjoročne ekonomske } \\
\text { prognoze; } \\
\text { 2. Formalni planovi; } \\
\text { 3. Diversifikacija; } \\
\text { 4. Službe za strateško planiranje }\end{array}$ \\
\hline 1970-1980. & $\begin{array}{l}\text { STRATEŠKO } \\
\text { POZICIONIRANjE }\end{array}$ & $\begin{array}{l}\text { 1. Analiza industrije; } \\
\text { 2. Segmentacija tržišta; } \\
\text { 3. Kriva iskustva; } \\
\text { 4. PIMS analiza; } \\
\text { 5. Portfolio menadžment }\end{array}$ \\
\hline 1980-1990. & $\begin{array}{l}\text { KONKURENTSKA } \\
\text { PREDNOST }\end{array}$ & $\begin{array}{l}\text { 1. Analiza resursa i internih } \\
\text { sposobnosti; } \\
\text { 2. Restruktuiranje i reinžinjering; } \\
\text { 3. Alijanse }\end{array}$ \\
\hline 1990-2000. & $\begin{array}{c}\text { STRATEGIJA ZA NOVU } \\
\text { EKONOMIJU }\end{array}$ & $\begin{array}{l}\text { 1. Strateške inovacije; } \\
\text { 2. Novi poslovni modeli; } \\
\text { 3. Tehnološke inovacije; } \\
\text { 4. Povećanje akcionarskog } \\
\text { kapitala }\end{array}$ \\
\hline od 2000. godine u primeni & $\begin{array}{c}\text { STRATEGIJA U NOVOM } \\
\text { VEKU }\end{array}$ & $\begin{array}{l}\text { 1. Društveno odgovorno } \\
\text { poslovanje; } \\
\text { 2. Poslovna etika; } \\
\text { 3. Globalne strategije; } \\
\text { 4. Nepredvidiva tržišta } \\
\end{array}$ \\
\hline
\end{tabular}

Ovde je bitno istaći da svaka od navedenih strategija ima svoj nivo organizacije na kojem se primenjuje, pa tako imamo: (1) korporativne, (2) poslovne i (3) funkcionalne strategije. ${ }^{35}$ Navedena klasifikacija strategija po nivoima organizacije uvažava različite nivoe menadžmenta, i to po sledećem: (1) vrhovni-topmenadžment, (2) srednji i (3) operativni, odnosno određeni nivo strategije precizira koji nivo menadžmenta određenu strategiju definiše i operacionalizuje.

\section{Razvoj savremenog strategijskog menadžmenta}

Pod uticajem globalizacije (mondijalizacije) sveta, enormno brzim razvojem nauke, tehnike i tehnologije, skraćivanjem životnog ciklusa proizvoda, stvara se klima uslova za modifikaciju strategijskog planiranja i njegovu evoluciju u viši nivo - strategijski menadž-

\footnotetext{
${ }^{35}$ Funkcionalnestrategijeseprimenjujuzaodređenefunkcije u preduzeću: marketing, proizvodnja i drugo.
} 
ment ili strateški menadžment prema jednom delu autora. U teoriji menadžmenta ovaj period se naziva i ,,upravljanje u Novom društvu“ prema knjizi istoimenog naziva od jednog od najpoznatijih teoretičara menadžmenta, ali i organizacije, Pitera F. Drakera. Karakteristika ovog perioda je na razvijanju novih pristupa i koncepata u menadžmentu sa tendencijom da neki postanu paradigme, a tu spadaju: (1) upravljanje u novom društvu, (2) teorija haosa, (3) organizacija koja uči, (4) reinženjering poslovnih procesa, (5) menadžment totalnog kvaliteta, (6) upravljanje promenama i (7) menadžment znanja.

Naime, tokom 80-tih i 90-tih godina 20. veka kod većine organizacija javlja se potreba za usavršavanjem postojećeg načina planiranja u skladu sa novim trendovima u okruženju, odnosno javlja se potreba za efikasnijom kontrolom, implementacijom i evaluacijom strategija organizacija. Direktna posledica navedenih potreba jeste nastajanje strategijskog menadžmenta, koji sa određenim varijacijama postoji i danas. Ovim promenama strategijsko planiranje je postalo samo podproces strategijskog menadžmenta kako je to i prikazano na Slici 1.

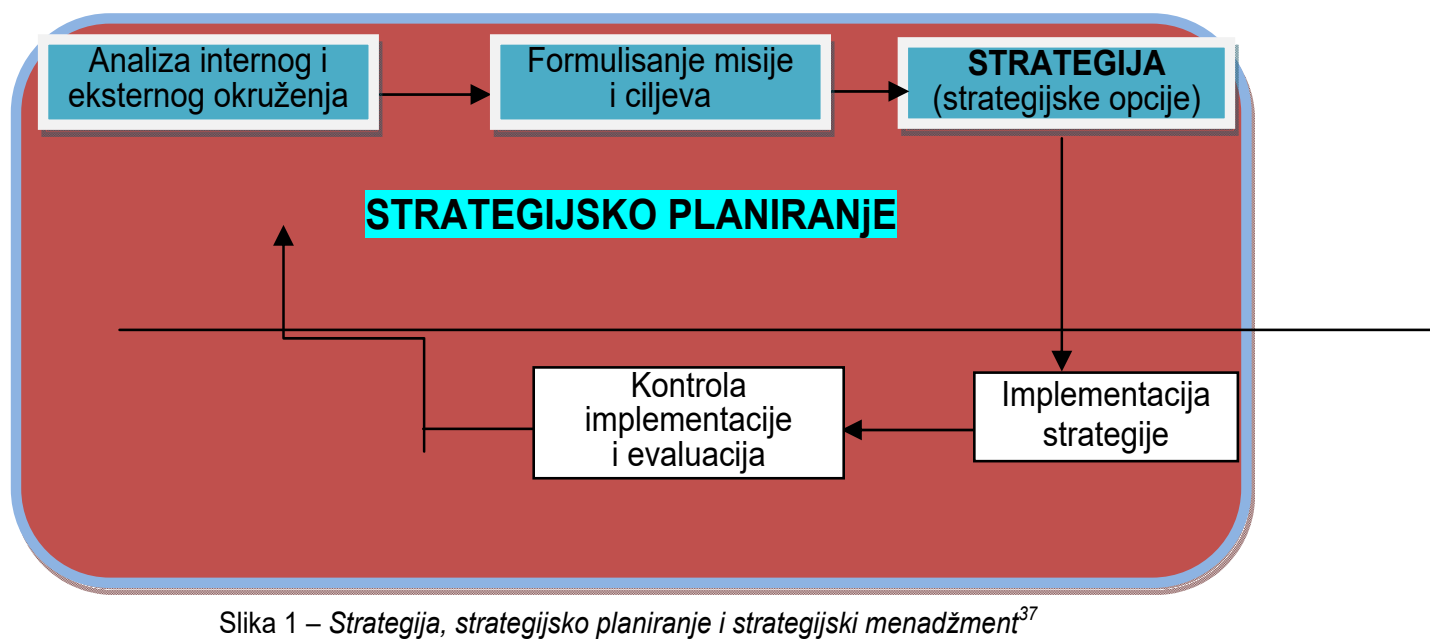

Osnovne karakteristike četvrte etape su: (1) donošenje strateških odluka je isključivo u nadležnosti vrhovnog menadžmenta i zahteva analizu uticaja faktora iz okruženja kao eksternog, tako i internog; (2) uticaj strateških odluka je dugoročan; (3) strategija organizacije je u korelaciji sa definisanim ciljevima; (4) strategija je u funkciji ostvarenja ciljeva; (5) stepen efikasnost sprovođenja strategije direktno je proporcionalan kvalitetu odnosa organizacije sa zainteresovanim stranama i (6) strategijskim menadžmentom je ostvaren interaktivni odnos organizacije i eksternog okruženja. Shodno činjenici da je strategijski menadžment kontinuiran i iterativan proces, odvijanje ovog procesa može se predstaviti kroz određeni broj sadržaja (faza) i funkcija (podprocesa). ${ }^{38}$ Ovo pitanje obrađujemo kroz

\footnotetext{
${ }^{36}$ Grč. paradigma - primer za ugled, obrazac, uzorak, uzor.

${ }^{37}$ Mihić, M., Koncept upravljanja organizacijom integrisanjem strateškog i projektnog menadžmenta, doktorska disertacija, Fakultet organizacionih nauka, Beograd, 2008.

${ }^{38}$ Johnson, G., Scholes, K., Exploring Corporate Strategy, Prentice-Hall, New Jersey, 1999.
} 
dve celine, u prvoj posebno objašnjavamo sadržaje ili prema jednom delu autora, modele strategijskog menadžmenta, koji se uokviruju fazama planiranja i implementacije strategije, dok u drugoj celini predstavljamo funkcije ili podprocese strategijskog menadžmenta.

\section{Specifičnosti razvoja strategijskog menadžmenta u sistemu odbrane}

Kako strategijski menadžment predstavlja naučnu disciplinu koja se bavi problemima formulisanja i implementacije strategije za ostvarivanje dugoročnih ciljeva organizacije. Primarno se razvija u okviru menadžmenta kao nauke i istražuje probleme koji se odnose na organizacije uopšte. Međutim, on se bavi i problemima koji se odnose na vojne i druge organizacije sistema odbrane. Da bi smo što potpunije mogli sagledati specifičnosti razvoja strategijskog menadžmenta u sistemu odbrane moramo poći od pojma sistema odbrane i njegovih razlika sa drugim sistemima društva. Prema Strategiji odbrane Republike Srbije, sistem odbrane je deo sistema nacionalne bezbednosti Republike Srbije (RS) i predstavlja jedinstvenu, strukturno uređenu celinu snaga i subjekata odbrane čij je cilj zaštita odbrambenih interesa Republike Srbije. Snage odbrane jesu ljudski i materijalni potencijali RS, odnosno organizovane strukture subjekata sistema odbrane, a subjekti sistema odbrane su: građani, državni organi, pravna lica, preduzetnici i Vojska Srbije. Sistem odbrane i svoju moć upravo temelji na sveukupnim ljudskim, materijalno-tehničkim i duhovnim potencijalima naroda. ${ }^{39}$

Razmatrajući razlike sistema odbrane u odnosu na druge organizacije i sisteme, obzirom da upravo one impliciraju model strategijskog menadžmenta koji se primenjuje, možemo zaključiti da se ogledaju u sledećem: (1) cilj postojanja sistema odbrane nije ostvarenje profita, već zadovoljenje određene potrebe društva; (2) menadžment sistema odbrane ili njegovih sastavnih celina nije samostalan, odnosno ne definiše organizacione ciljeve, već se oni definisani dobijaju od strane nadležnog organa državne uprave i menadžment je zadužen samo za dostizanje zadatih ciljeva; (3) resurse za dostizanje ciljeva sistem odbrane dobija od države; (4) postojanje sistema odbrane ne zavisi od uspešnosti njenog poslovanja, već isključivo od procene državnih organa da li ima potrebe za njenim postojanjem i (5) evaluirati rezultate sistema odbrane je mnogo kompleksnije nego što je u drugim organizacijama. ${ }^{40}$

Nakon što što smo definisali sistem i naveli subjekte sistema odbrane i njegove distinkcije u odnosu na druge druge organizacije i sisteme u daljem delu rad bavićemo se razvojem primene strategijskog menadžmenta u sistemu odbrane. Može se reći da je ključ uspešnosti svakog razvijenog sistema odbrane u održavanju pravilnog balansa potreba i mogućnosti društva, odnosno usklađenosti između troškova sistema i raspoloživih finansijskih sredstava. Ključnu ulogu u celokupnom procesu ima funkcija strategijskog planiranja, jer se u okviru nje ili kroz nju realizuje spoj između programa, projekata, aktivnosti, zadataka i finansijskih sredstava. Zato se u mnogim teorijskim izvorima i analizama prakse funkcionisanja složenih bezbednosnih i odbrambenih sistema daje primat funkciji strategijskog planiranja. Bez njenog pravilnog pozicioniranja u okviru strategijskog menadžmenta, u dužem periodu, nije moguće imati uspeha u domenu bilo koje druge sistemske funkcije.

\footnotetext{
${ }^{39}$ Kovač, M., Stojković, D., Strategijsko planiranje odbrane, Vojnoizdavački zavod, Beograd, 2009, str. 271.

${ }^{40}$ Kovačević, N., Domjančić S., i Kovač M., Strategijski menadžment u vojnoorganizacionom sistemima, Vojno delo septembar-okotbar 2018, str. 272.
} 
$\mathrm{Na}$ osnovu teorijskog pristupa konceptu strategijskog menadžmenta u sistema odbrane kao i iskustava u primeni istog u daljem tekstu koncentrišemo se na jedan koncept strategijskog menadžmenta u sistemu odbrane koji je od presudnog značaja za realizaciju funkcije planiranja i budžetiranja potreba i rashoda odbrane u okviru javnih potreba i rashoda i za izvršavanje državnog budžeta. Posmatraćemo skup organizacionih rešenja, metoda i postupaka, najčešće poznat pod zajedničkim nazivom - sistem PPBI. ${ }^{41}$

Imajući u vidu da su struktura, upravljanje i načela funkcionisanja sistema odbrane utvrđena Strategijom odbrane, a da na organizovanje i funkcionisanje strategijskog menadžmenta, odnosno sistema PPBI, opredeljujuće utiče struktura sistema odbrane. Kako smo naveli sistem odbrane je složen organizacioni sistem namenjen za zaštitu vitalnih odbrambenih interesa RS. Upravljanje ovako složenim organizacionim sistemom predstavlja izazov za rukovodstvo sistema odbrane i znatno utiče na organizovanje i funkcionisanje strategijskog menadžmenta, odnosno sistema PPBI.

Istorijski gledano razvoj pomenutog koncepta PPBI nastao je 60-tih godina 20. veka. Sistem PPBI prvobitno je nastao i implementiran u Ministarstvu odbrane SAD-a i nazvan je Sistem planiranja, programiranja i budžetiranja (engl: Planning, Programming and Budgeting System, u daljem tekstu: PPBS). Sistem PPBS nastao je kao odgovor na probleme nedostatka instrumenata za upravljanje i donošenje jasnih odluka po važnim pitanjima nacionalne bezbednosti. U osnovi, sistem PPBS bio je korišćen u procesu donošenja odluka radi određivanja organizacionih ciljeva, izbora mera za njihovo praćenje i primene izabranih varijanti delovanja. Osnovni cilj Sistema PPBS bio je unifikacija funkcija planiranja, programiranja i budžetiranja. ${ }^{42}$

Taj sistem je omogućavao određivanje ciljeva, alokaciju resursa i usmeravanje programa ka određenim ciljevima. U međuvremenu sistem je evoluirao, a najznačajnije modifikacije izvršene su 1973. i 2003. godine. U toku 1973. godine izvršeno je njegovo poboljšanje, uvođenjem faze izvršenja, pa je stvoren sistem planiranja, programiranja, budžetiranja i izvršenja (engl: Planning, Programming, Budgeting and Execution System, u daljem tekstu Sistem PPBES). ${ }^{43} \mathrm{U}$ praktičnoj primeni Sistema PPBES uočeno je da to nije samo sistem, nego i proces. Tako je 2003. godine u okviru Ministarstva odbrane SADa i Kopnene vojske oružanih snaga SAD-a stvoren proces planiranja, programiranja, budžetiranja i izvršenja, proces PPBI i predstavljao je šestogodišnji ciklični proces sastavljen od faza planiranje, programiranje, budžetiranje i izvršenje.

Prvobitni Sistem PPBS evoluirao je u Sistem PPBES i proces PPBI. Na taj način, u savremenoj primeni, koncept PPBI posmatra se i kao sistem i kao proces. Zbog pozitivnih iskustava u primeni i sistema i procesa, koncept PPBI našao je široku primenu u sistemima odbrane velikog broja država, ali i u najvećim svetskim organizacijama.

\footnotetext{
${ }^{41}$ Kovač, M., Osnovne postavke projektovanja i uvođenja sistema planiranja, programiranja, budžetiranja $i$ izvršenja, Vojno delo, Beograd, 2008, godine, str. 2.

42 DonVito, P., The Essentials of a Planning-Programing-Budgeting System, 1969, The RAND Corporation, pp. 4124

${ }^{43}$ Kovač M., Osnovne postavke projektovanja i uvođenja sistema planiranja, programiranja, budžetiranja $\mathrm{i}$ izvršenja, Vojno delo, Beograd, 2008. godine, str. 8.
} 
U Ministarstvu odbrane i Vojsci Srbije 2009. godine je uveden sistem planiranja, programiranja i budžetiranja (PPBI) kao osnovni model planiranja u odbrani. ${ }^{44}$ Kao proces sastoji se od četiri faze - (1) planiranje, (2) programiranje, (3) budžetiranje i (4) izvršenje. ${ }^{45}$ Sistem PPBI kao koncept strategijskog menadžmenta koji omogućava razvoj sistema odbrane dostizanjem i održavanjem sposobnosti potrebnih za izvršavanje poslova, misija i zadataka. Na osnovu teorijskog pristupa konceptu PPBI i iskustava u primeni tog koncepta u sistemima odbrane, kao i svetskim organizacijama, taj koncept može da se posmatra dvojako: kao sistem i kao proces. Koncept PPBI može da se posmatra kao sistem jer ima svoju strukturu i pravila funkcionisanja, a kao proces jer je kontinuiran i sastoji se iz četiri faze: planiranje, programiranje, budžetiranje i izvršenje. S tim u vezi, a radi razumevanja koncepta $\mathrm{PPBI}$ u sistemu odbrane, sagledana je organizacija sistema PPBI i izvršena analiza tog koncepta kao procesa.

Sistem PPBI organizovan je na strategijskom i operativnom nivou. Na strategijskom nivou organizovan je u Ministarstvu odbrane, a na operativnom u komandama Kopnene vojske, Ratnog vazduhoplovstva i protivvazduhoplovne odbrane i Komande za obuku. Najviši stručni organ za planiranje, programiranje i izvršenje jeste Uprava za strategijsko planiranje, a za budžetiranje Uprava za budžet.

Upravno-stručni i nadzorni organ, nadležan za planiranje, organizaciju i funkcionisanja sistema logističke podrške u sistemu odbrane jeste Sektor za materijalne resurse, a njegove nadležnosti su: istraživanje, razvoj, proizvodnja i promet naoružanja i vojne opreme; opremanje i naoružavanje Vojske Srbije i drugih snaga odbrane; planiranje, organizovanje, nadzor i izgradnja vojnih objekata i planiranje i organizovanje transporta za potrebe Ministarstva odbrane i Vojske. Organizaciona struktura Sektora za materijalne resurse prikazana je na Slici 2.

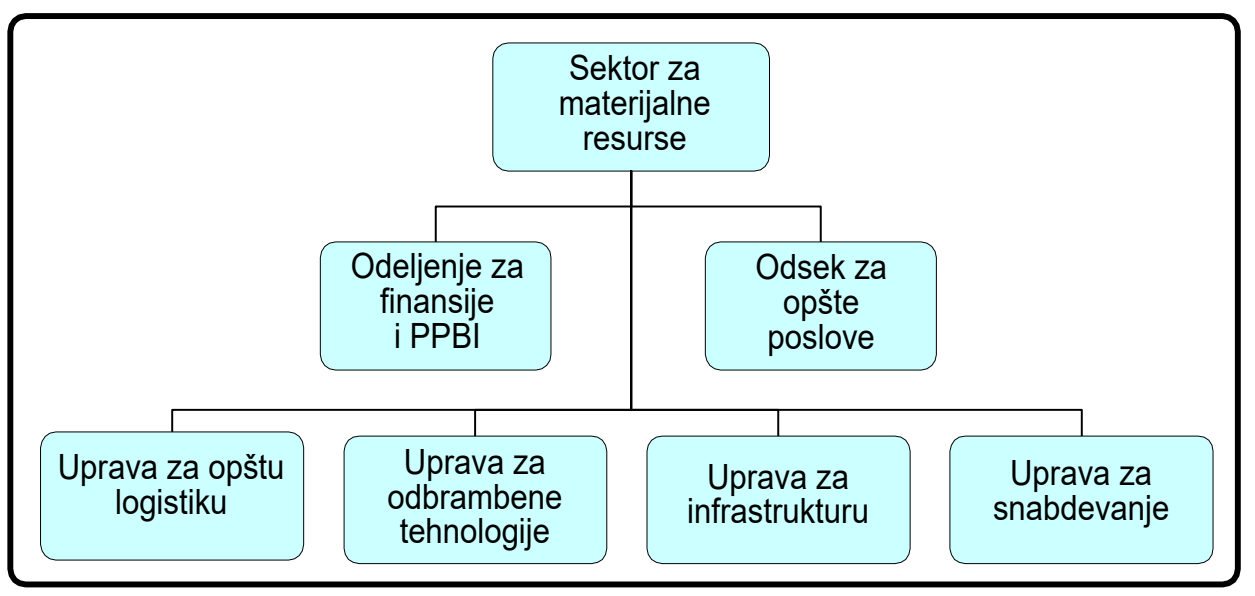

Slika 2 - Organizaciona struktura Sektora za materijaln e resurse Ministarstva odbrane RS

\footnotetext{
${ }^{44}$ Ministarstvo odbrane, Bela knjiga odbrane, Medija centar Beograd, 2010. godina, str. 25.

${ }^{45}$ Kovač, M., Stojković, D., Strategijsko planiranje odbrane, Vojnoizdavački zavod, Beograd, 2009.godine, str.446.
} 
Osnovni preduslov za uspešno izvršavanje poslova Ministarstva odbrane i misija i zadataka Vojske jeste odgovarajuće finansiranje odbrane. Osnovna unutrašnja jedinica Ministarstva odbrane koja obavlja poslove iz oblasti finansiranja odbrane jeste Sektor za budžet i finansije, koji je između ostalog nadležan za: pripremu nacrta propisa iz oblasti finansijskog poslovanja; planiranje, organizovanje, izvršenje i kontrolu materijalno-finansijskog poslovanja; finansijsku politiku Ministarstva odbrane; planiranje budžeta odbrane; planiranje, programiranje, budžetiranje i sprovođenje finansijskog plana za potrebe Ministarstva odbrane i organizovanje informacionog sistema iz oblasti planiranja, finansiranja i materijalno-finansijskog poslovanja.

Izvršne organe sistema PPBI na strategijskom nivou čine organizacione jedinice za finansije i PPBI u osnovnim i užim organizacionim jedinicama. Na operativnom nivou formirane su organizacione jedinice za PPBI u komandama Kopnene vojske, Ratnog vazduhoplovstva i protivvazduhoplovne odbrane i Komande za obuku. Organizacione jedinice na strategijskom i operativnom nivou učestvuju u svim faza, a direktno su nadležne za izradu predloga programa, programskih aktivnosti i projekata za osnovne i uže organizacione jedinice i operativne sastave. Aktivna uloga tih organizacionih jedinica dolazi do izražaja u procesu izvršenja, odnosno realizovanja programa, programskih aktivnosti i projekata, praćenju realizacije i izveštavanju o rezultatima. planiranje, programiranje, budžetiranje i izvršenje u sistemu odbrane predstavlja i proces.

Kao što je rečeno, planiranje, programiranje, budžetiranje i izvršenje može da se posmatra i kao složen, višefazan proces. Proces PPBI sastoji se od četiri faze koje su međusobno povezane i početak jedne uslovljen je završetkom druge. Korelacija faza procesa PPBI prikazana je na Slici 3.

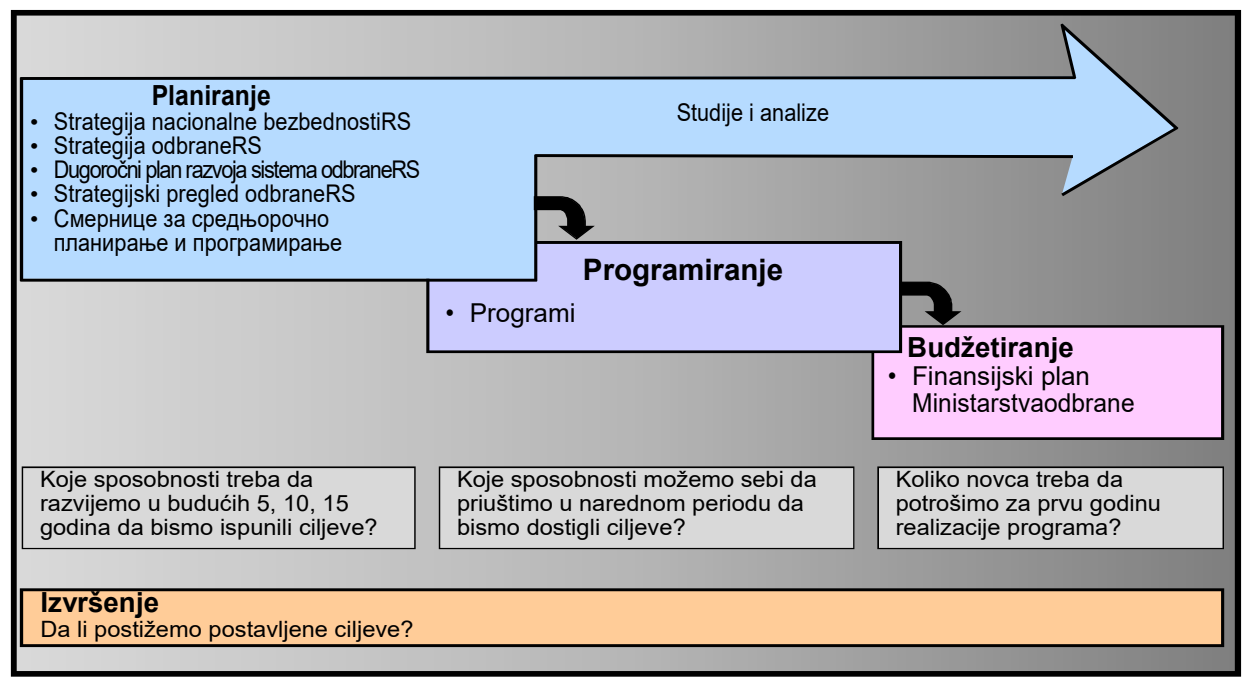

Slika 3 - Faze procesa PPBI 
Kao što se vidi planiranje započinje izradom dokumenata dugoročnog planiranja i završava izradom Smernica za srednjoročno planiranje i programiranje, koje predstavljaju osnovu za programiranje. ${ }^{46}$ Izradom Srednjoročnog plana i programa završava se faza programiranja i započinje faza budžetiranja čiji je rezultat Finansijski plan. Faza izvršenja praktično obuhvata vreme trajanja prethodne tri faze, odnosno obuhvata izvršenje svih dokumenta donetih u tim fazama. Međutim, u praksi ne može se jasno odrediti završetak jedne, a početak druge faze, već se vrlo često aktivnosti preklapaju (posebno programiranje i budžetiranje).

Kada govorimo o kratkoročnom planiranju značajno bi bilo napomenuti da isto nije određeno Zakonom o odbrani, međutim to ne znači da je manje značajno za sistem odbrane. Osnovni dokumenti kratkoročnog planiranja su: (1) Ministarsko uputstvo, (2) godišnji planovi nosilaca funkcija u sistemu odbrane i (3) godišnji planovi organizacionih jedinica Ministarstva odbrane i Vojske. Kratkoročnim planiranjem načelno se određuju kratkoročni ciljevi sistema odbrane i načini za njihovo ostvarenje. Takođe kratkoročnim ciljevima operacionalizuju se dugoročni ciljevi sistema odbrane.

Implementacija strategija je proces pomoću kojeg se strategije stavljaju u akciju kroz razvoj programa, budžeta, procedura i pravila. Uspešna implementacija podrazumeva jasnu ideju o raznim pitanjima (neophodne promene, kako ovladati organizacijskom kulturom i drugo), što može uključivati i promene unutar samog sistema koje se, najčešće, sprovode na srednjem i nižim nivoima sistema.

Implementacija Strategije razvoja sposobnosti sistema odbrane zasniva se na dva ključna procesa: (1) planiranje, programiranje, budžetiranje i izvršenje (PPBI), koje predstavlja sistem za upravljanje resursima odbrane radi održavanja i razvoja sposobnosti Ministarstva odbrane za obavljanje poslova u skladu sa nadležnostima i izvršavanje dodeljenih misija i zadataka Vojske Srbije i (2) razvoj Vojske Srbije zasnovan na sposobnostima. Još jedna specifičnost sistema odbrane ogleda se u tome da strategijski nivo često nema ovlašćenja da samostalno određuje misiju i ciljeve organizacije, ali može da ostvari značajne refleksije na nadležne organe državne uprave prilikom njihovog određivanja.

\section{Zaključak}

Strategijski menadžment predstavlja naučnu disciplinu koja se bavi problemima formulisanja i implementacije strategije za ostvarivanje dugoročnih ciljeva organizacije. Primarno se razvija u okviru menadžmenta kao nauke i istražuje probleme koji se odnose na organizacije uopšte i nesumnjivo će se dalje razvijati i njegovu modifikaciju možemo očekivati shodno inovacijama u svim sferama ljudske delatnosti, prevashodno u nauci i ekonomiji, pri čemu uspešno istražuje i probleme koji se tiču upravljanja vojnim i i drugim organizacijama sistema odbrane. Možemo očekivati da strategijski menadžment u budućnosti sazreva kao naučna disciplina i da se dodatno rafinišu njene paradigme zajedno sa unapređenjem i razvojem praktične primene kako u društvu tako i u sistemu odbrane.

\footnotetext{
${ }^{46}$ Kovač, M., Osnovne postavke projektovanja i uvođenja sistema planiranja, programiranja, budžetiranja i izvršenja, Vojno delo, Beograd, 2008. g.
} 
Strategijski menadžment je disciplina menadžmenta, koja će ako želimo da opišemo strategijski menadžment onda treba reći da on predstavlja svojevrsno sučeljavanje organizacije sa ambijentom u kojem organizacija egzistira, i želi da ostvari ciljeve u budućnosti, a koga karakteriše kompleksnost, turbulentnost i ambivalentnost na jednoj, kao i dugoročnost posledica planskih odluka upravljačkih struktura organizacije, a naročito kada govorimo o angažovanju resursa, na drugoj strani.

Na osnovu rezimiranja iznetih stavova možemo zaključiti sledeće: (1) nemoguće je objasniti strategijski menadžment ukoliko se ne razmatra organizacija u kojoj se on primenjuje, odnosno menadžment i organizacija su u neraskidivoj vezi; (2) strategijski menadžment u okvirima sistema odbrane, posebno vojne organizacije je primenjiv, svrsishodan i predstavlja differentia specifica strategijskog menadžmenta koji se primenjuje u drugim delatnostima; (3) strategijski menadžment u sistemu odbrane bavi se svim aktivnostima iz domena odbrane, izuzev izvođenja operacija; (4) neophodan je dodatni rad vojne organizacije na polju terminološkog određenja i suštinskog shvatanja funkcija i faza ove vrste menadžmenta radi olakšanja njegove primene u praksi; (5) postoji potreba za transferom znanja, a prevashodno iskustava iz prakse, između strategijskog menadžmenta koji se primenjuje u vojnim organizacijama sa onim koji se primenjuje u drugim delatnosti i (6) shodno značaju funkcije odbrane zemlje u proces primene ove vrste menadžmenta neophodno je involvirati celokupne resurse države (prevashodno ljudske) i permanentno pratiti njegov dalji tok i razvoj.

Nema krajnjih (za sva vremena utvrđenih) ciljeva u izuzetno složenim procesima i sistemima na koje utiče veliki broj faktora iz i izvan sistema. Međutim ima i treba_da bude ozbiljnih i kompetentnih nastojanja da se strategije sistema utvrde, implementiraju, kontrolišu i evaluiraju na što je moguće efektivniji i efikasniji način, za dostizanje željenih stanja sistema, u čemu menadžment ima najveću ulogu. Sistem odbrane je najsloženiji sistem svake države, jer se preko njega prepliću sve sfere ljudske delatnosti, usmerene na stvaranje optimalnih uslova za opšti prosperitet i razvoj zemlje.

Kao što je istaknuto sistem odbrane izložen je brojnim izazovima, rizicima i pretnjama bezbednosti, a da bi im se sistem odbrane uspešno suprotstavio treba da poseduje određene sposobnosti. Dostizanje potrebnih sposobnosti omogućava se sprovođenjem procesa strategijskog menadžmenta u sistemu odbrane. lako je razvijeno više različitih koncepata strategijskog menadžmenta u sistemu odbrane se najčešće primenjuje sistem PPBI.

\section{Literatura}

[1] Ansoff, H., I., Corporate Strategy, Penguin Books, London, 1987.

[2] Васић Ж., Сајферт Д., Јевремовић М., Основи менацмента, Висока школа електротехнике и рачунарства струкових студија, Београд, 2013.

[3] David, F., Strategic management: concepts and cases, 11th ed., Pearson Prentice Hall, New Jersey, 2007.

[4] Dess, Lumpkin i Eisner, Strategijski menadžment, Data Status, Beograd , 2007.

[5] DonVito, P., The Essentials of a Planning-Programing-Budgeting System, 1969, The RAND Corporation.

[6] Grant R., Contemporary Strategy Analysis, VI Edition, Blackwell Publishing, Oxford, 2007.

[7] Јовановић П. Лексикон менацмента, Факултет организационих наука, Београд, 2003. 
[8] Johnson, G., Scholes, K., Exploring Corporate Strategy, Prentice-Hall, New Jersey, 1999.

[9] Ерић, Д., Увод у меначмента, Чигоја штампа, Београд, 2000.

[10] Група аутора, Методологија ратне вештине, скрипта, Центар војних школа Београд, 1996.

[11] Илић Б., Меначмент, Факултет за трговину и банкарство, Инеграф, Београд, 2002.

[12] Јовановић П., Менацмент - теорија и пракса, Висока школа за пројектни менаџмент, Београд, 2007.

[13] Јовановић П., Стратегијски менацмент, Зухра, Београд, 2007.

[14] Ковач, М., Стојковић, Д., Стратегијско планирање одбране, Војноиздавачки завод, Београд, 2009.

[15] Ковач, М., Основне поставке пројектовања и увођења система планирања, програмирања, бучетирања и извршења, Војно дело, Београд, 2008.

[16] Ковачевић, Н., Домјанчић С., и Ковач М., Стратегијски меначмент у војноорганизационом системима, Војно дело, септембар-октобар 2018.

[17] Михић, М., Концепт управљања организацијом интегрисањем стратешког и пројектног менацмента, докторска дисертација, Факултет организационих наука, Београд, 2008.

[18] Министарство одбране, Бела књига одбране, Медија центар Београд, 2010.

[19] Robbins, S., Coulter, M., Management, 9th ed., Pearson Prentice Hall, New Jersey, 2009.

[20] Стојковић, Д., Ђурић Н., Благојевић С., Повезаност стратегијског меначмента и наука одбране, Војно дело , Београд, 2011.

[21] Талијан, М., Безбедносни менацмент у супротстављању тероризму и борби против тероризма, Медија центар Одбрана, Београд, 2012.

[22] Тодоровић Ј., Ђуричин Д., Јаношевић С., Стратегијски менацмент, Институт за тржишна истраживања, Београд, 2000.

[23] Тодосијевић Р., Стратегијски менацмент-теоријске поставке, Економски факултет Суботица, Универзитет у Новом Саду, Суботица, 2009.

[24] Certo, S., Certo., T., Modern Management: Concepts and Skills, 11th ed., Pearson Prentice Hall, New Jersey, 2009.

[25] Von Bertalanffy L., General system theory, George Brayiller, New York, 1968.

[26] Wren, D.A., Vioch, D., Menadžment, proces struktura i ponašanje, privredni pregled - Grmeč, Beograd, 1994. 